Article

\title{
A Method for WWTP Sludge Valorization through Hygienization by Electron Beam Treatment
}

\author{
Marcin Sudlitz * and Andrzej G. Chmielewski (D) \\ Institute of Nuclear Chemistry and Technology, 03-195 Warsaw, Poland; A.Chmielewski@ichtj.waw.pl \\ * Correspondence: m.sudlitz@ichtj.waw.pl
}

Citation: Sudlitz, M.; Chmielewski, A.G. A Method for WWTP Sludge Valorization through Hygienization by Electron Beam Treatment. Fermentation 2021, 7, 302. https:// doi.org/10.3390/fermentation7040302

Academic Editor: Eldon R. Rene

Received: 10 October 2021

Accepted: 6 December 2021

Published: 9 December 2021

Publisher's Note: MDPI stays neutral with regard to jurisdictional claims in published maps and institutional affiliations.

Copyright: (c) 2021 by the authors. Licensee MDPI, Basel, Switzerland. This article is an open access article distributed under the terms and conditions of the Creative Commons Attribution (CC BY) license (https:/ / creativecommons.org/licenses/by/ $4.0 /)$.

\begin{abstract}
This work reports on municipal sludge hygienization using electron beams. Three types of sewage sludge from two municipal wastewater treatment plants were tested: preliminary sludge with $4 \%$ TS, postflotation sludge with $2.5 \%$ TS and thickened preliminary sludge with $10 \%$ TS The analysis of reference samples demonstrated the presence of bacteria and helminths ova in all examined samples. For the study of hygienization, electron beams from two types of accelerators, linear (Elektronika 10/10) and single cavity (ILU-6), were applied. For each type of accelerator, different irradiation methods were used: irradiation in sealed polyethylene bags using conveyor and flow irradiation installation. Experiments showed that the doses necessary for the elimination of mentioned pathogens were $4 \mathrm{kGy}$ for preliminary sludge, $4 \mathrm{kGy}$ for postflotation sludge and $5.5 \mathrm{kGy}$ for preliminary sludge. The differences between the amounts of initial pathogens in preliminary and thickened preliminary sludge were marginal. It is possible that the higher irradiation dose required to hygienize thickened sludge resulted from higher TS concentration.
\end{abstract}

Keywords: sewage sludge; electron beam; helminths; pathogenic bacteria; hygienization

\section{Introduction}

Sewage sludge is a waste formed in the process of municipal and industrial wastewater in wastewater treatment plants (WWTP). Wastewater delivered to WWTP is filtered for large particles such as trash, small branches, etc., and grit, and directed to settlers, where it is thickened to about $2-4 \%$ dry mass. The water phase is then directed to an aerobic biological purification process while sediment is removed from the settler as primary sludge. In the aerobic biological purification process, organic pollutants containing carbon and sometimes nitrogen and phosphorus are removed by biological processes in aerated reactors. After a certain duration, bacteria cells are produced, and thus a suspension is obtained which is next directed to a settler where a separated water phase with low COD is removed outside of the WWTP, then sludge is removed from the settler and partially recirculated to the aerobic biological reactor as a source of microorganisms, and the rest is removed as excess sludge. Some WWTPs can operate some custom installations, where different types of sludge can be obtained [1].

Municipal wastewater contains mostly human and animal excrements. Human waste occurring in municipal sewage is both domestic and of hospital origin. Thus, a huge variety of pathogenic microorganisms such as viruses (e.g., adenovirus, hepatitis virus, human calcivirus, poliovirus), fungi, and pathogenic bacteria (e.g., E. coli, Salmonella spp., Vibrio cholerae) [2] can be found in wastewater streams entering WWTPs. Another common problem is the occurrence of parasites (helminths as well as protozoa) and their eggs [2].

According to the Statistical Yearbook of Poland, the amount of sewage sludge generated at WWTPs annually in the country is currently slightly increasing [3]. These data are presented in Figure 1.

It has been forbidden to store sewage sludge on landfills since 2016 [4], which has caused an emerging need to utilize sludge from WWTPs in other, more practical ways. 
Agricultural use seems to be promising. Nevertheless, the presence of the pathogens mentioned above requires the introduction of a hygienization process in sewage sludge pretreatment before such use, requiring the removal of some bacteria, parasites and their ova from the sludge [5].

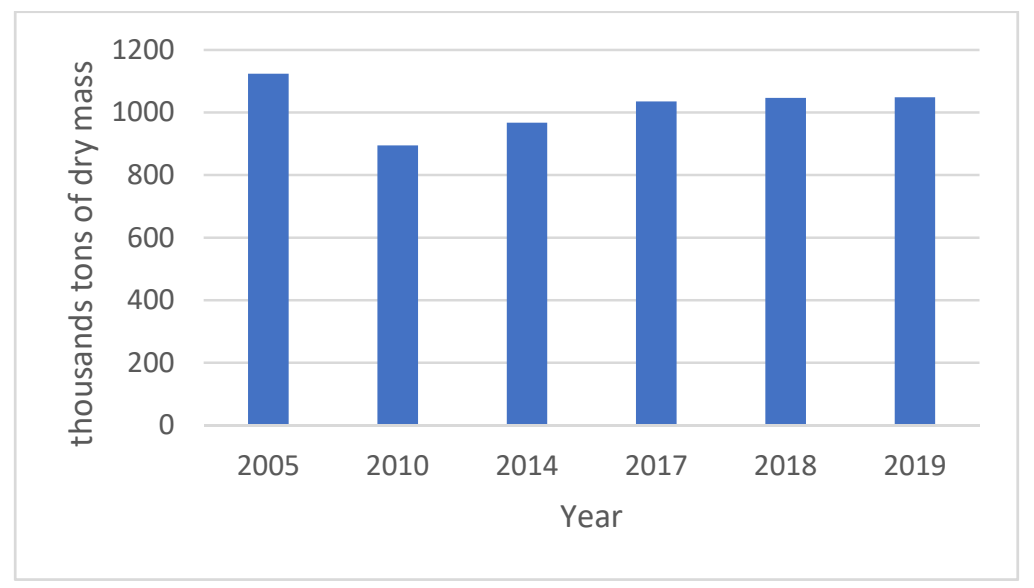

Figure 1. Amount (thousands of tons of dry mass) of sludge generated in Poland (municipal and industrial WWTPs) in the years 2005, 2010, 2014, 2017, 2018 and 2019 [3].

The problem with the presence of parasite eggs in sewage sludge is still current. Amahmid et al. tested occurrence of Giardia cysts and roundworm (Ascaris) eggs in municipal wastewater and municipal wastewater sediment sampled from two basins. Experiments indicated that roundworm eggs were present in $39.5 \%$ of tested samples of raw wastewater, $83.3 \%$ of tested samples of wastewater sediments from the entrance to the first basin and $70.8 \%$ of samples of wastewater sediments from the exit from the first basin. No Ascaris eggs were found in second basin wastewater sediments. Giardia cysts were present in $50 \%$ of tested raw wastewater samples, in $25 \%$ of tested samples of wastewater sediments from the entrance to the first basin and in $5.6 \%$ of samples of wastewater sediments from the exit from the first basin. In the second basin wastewater sediments there were no Giardia cysts either [6].

S. Chaoua et al. showed results of testing raw sewage and sewage sludge from two different WWTPs in Morocco for the presence of parasite eggs. For the first WWTP in Marrakech, in $88.32 \%$ of tested samples of wastewater Ascaris lumbricoides eggs were detected. For Ancylostoma duodenale, Trichuris Trichuria, Capillaria spp., Taenia spp. And Hymenolepis spp., test results were positive for $4.96 \%, 0.97 \%, 0.89 \%, 3.04 \%$ and $1.82 \%$ of tested samples, respectively. In the case of sewage sludge from Marrakech WWTP, Ascaris lumbricoides eggs were present in $95.11 \%$ of tested samples, $3.83 \%$ - Ancylostoma duodenale, $0.52 \%$-Trichuris Trichuria and 0.4\%-Taenia spp. For the second WWTP in Chichaoua, in $88.08 \%$ of tested samples of wastewater Ascaris lumbricoides eggs were detected. For Ancylostoma duodenale, Trichuris Trichuria and Capillaria spp. test results were positive for $5.07 \%, 3.53 \%, 3.3 \%$ of tested samples, respectively. No eggs were detected for Taenia spp. and Hymenolepis spp. In the case of sewage sludge from Chichaoua WWTP, Ascaris lumbricoides eggs were present in $29 \%$ of the tested samples, $2.33 \%$-Ancylostoma duodenale, $0.66 \%$-Trichuris Trichuria and $1 \%$-Capillaria spp. [7].

However, the presence of helminths eggs is not only a problem in African countries. Recent studies have showed that eggs of human whipworm, human roundworm and animal roundworm (Ascaris sp., Trichuris sp. and Toxocara sp.-ATT) occur in sewage sludge across Poland. Zdybel et al. tested 17 samples from seven separate districts in Poland. Samples were collected from different steps of the wastewater purification process. The authors tested raw sewage, sludge from grit removal, preliminary sludge, secondary sludge, digestate and thickened sludge. ATT eggs were found in all types of samples, and the percentages of positive tests were $46 \%, 11 \%, 76 \%, 44 \%, 100 \%$ and $82 \%$, respectively [8]. 
Another paper showed the results of testing 92 samples of varying sizes from WWTPs from 16 regions of Poland. In this case, ATT eggs were the subject of study as well. In 91 of the 92 cases examined, ATT eggs were found, and Toxocara spp. were the most common [9]. G. Hudzik and D. Wodzisławska-Czapla between 2003 and 2009 tested 546 samples of sewage sludge taken from WWTPs in southern Poland. Sludge samples were tested for presence of Ascaris sp. and Trichuris sp. From all tested samples, the presence of eggs of mentioned parasites was confirmed in 35 (6.56\%). The authors also noticed, that Ascaris sp. were occurring more frequently [10].

The lethality of ionizing radiation on living organisms is well-known. The irradiation of water environments causes water radiolysis. This creates highly reactive chemical species, such as hydroxyl radicals, ${ }^{\bullet} \mathrm{OH}$, hydrogen radicals, ${ }^{\bullet} \mathrm{H}$, and solvated electrons $\mathrm{e}^{-}$aq. [11]. These species, especially ${ }^{\bullet} \mathrm{OH}$ radicals, can interact with DNA, damaging it in a mechanism called the "indirect effect." Another mechanism is the direct effect, where energy is deposited directly into a DNA molecule. Both of these mechanisms can cause irreparable damage to DNA strands and thus can kill cells or makes them unable to reproduce [12]. Irradiation is a known and used method to hygienize sewage sludge. Several papers describe this method as an effective way to remove pathogens, especially in India, where gamma radiation is applied [13-15]. Electron beams have been tested for the same purposes in Poland [16], South Korea [17] and other countries. T.T. Naign et al. tested the total bacteria content in industrial and municipal wastewater and sludge obtained from that wastewater after irradiation using a Co-60 source. Their experiments showed that the dose necessary to remove all bacteria from wastewater was $4 \mathrm{kGy}$, while for sludge it was $7 \mathrm{kGy}$ [18]. However, Chmielewski et al. showed that a $7 \mathrm{kGy}$ dose reduced total bacteria content from $1.1 \times 10^{9}$ to $1.1 \times 10^{5}$ in sewage sludge thickened to $35 \%$ dry mass, even though ATT eggs were removed totally using a 6 kGy dose [16]. L. Chu et al. investigated the influence of gamma irradiation of sewage sludge obtained in the anoxic-anaerobic-oxic process. Ts content varied from $1.1 \%$ to $1.4 \%$ and doses of ionizing radiation varied from 0-25 kGy. Experiments showed that total amount of culturable bacteria decreased from initial $1.4 \times 10^{6}$ to $2.7 \times 10^{3}$ after samples were irradiated to $25 \mathrm{kGy}$. Authors claimed that a $5 \mathrm{kGy}$ dose inactivated $91 \%$ of culturable bacteria, while $25 \mathrm{kGy}$ inactivated $99 \%$ culturable bacteria [19]. Engohang-Ndong et al. examined the influence of electron beam irradiation of preliminary sewage sludge on bacteria (total heterotrophic bacteria-THB, total coliform-TC and fecal coliform-FC) and Ascaris sp. eggs removal. Sludge samples had $15 \%$ TS, and a $3 \mathrm{MeV}$ electron accelerator was used and doses used were: $2.7 ; 6.7$; 13.2; 25.7 and $30.7 \mathrm{kGy}$. After irradiation of the sludge sample with $6.7 \mathrm{kGy}, 31 \% \pm 15 \%$ THB survived, while for TC and FC these values was $0.85 \% \pm 0.23 \%$ and $1.85 \% \pm 0.65 \%$, respectively. After irradiation with $13.2 \mathrm{kGy}, 8.9 \% \pm 1.3 \%$ of THB survived while TC and FC were removed completely. To remove THB to an insignificant level, $25.7 \mathrm{kGy}$ was required. To remove all Ascaris sp. eggs a $25.7 \mathrm{kGy}$ dose was also needed, however at a dose of $13.2 \mathrm{kGy}$ only $2 \% \pm 0.03 \%$ of Ascaris sp. eggs survived. The authors also estimated that $14.5 \mathrm{kGy}$ would be enough to achieve less than one Ascaris sp. egg per four grams TS, which is the minimum requirement for class A sludge according to EPA standards [20]. However, in these solutions, hygienization was only one objective of the method applied. The present study proves that not all pathogens are removed through the wastewater treatment process normally used in WWTPs. Additionally, methane fermentation in mesofilic conditions process may not remove helminths eggs and bacteria, and a digestate without hygienization is not a safe organic fertilizer (dewatered or in liquid form) [21,22]. However, some results showed that thermophilic anaerobic digestion can remove Salmonella spp. Enterococcus and Ascaris Suum from digested sewage sludge [23]. Sludge can also be transformed into fertilizer instead of being utilized for an anaerobic digestion process; in these cases, hygienization is even more important.

In case of the use of ionizing radiation to hygienize sewage sludge, an electron accelerator seems to be a better solution in comparison to isotope gamma sources, however such 
a choice requires a low-cost electricity supply, which is very important for the profitability. This can be solved by biogas production and electricity generation on site.

In this paper, experiments with the removal of pathogens from local WWTPs sewage sludge using electron beam irradiation are presented.

\section{Materials and Methods}

\section{Sample Preparation and Irradiation}

For the experiments, a number of sewage sludge samples were used, but both WWTPs at which samples were collected are located relatively close to Warsaw, Poland. The first type of sample used for the tests was preliminary sludge from WWTP 1, located around $20 \mathrm{~km}$ west of Warsaw. This sludge was obtained in the first step of wastewater purification by the sedimentation of solid particles after the stream of raw wastewater entered the WWTP. That sludge had $4 \%$ TS.

Another type was postflotation sludge obtained in a fixed-bed bioreactor purification process in WWTP 1. Low-SCOD $\left(1000-1500 \mathrm{mgO}_{2} / \mathrm{L}\right)$ wastewater from a nearby yeast factory and water phase from primary settlers for municipal wastewater were directed to packed bed biological reactors, and a mixture of both mentioned types of wastewater were sprayed above the reactor. Liquid was perfused through carriers and then recirculated. Part of that recirculation stream, with some biofilm peeled away from the carriers, was pumped away, mixed with PIX coagulant and channeled to microbubble flotation process. Samples of that sludge used for the experiments had $2.5 \%$ TS.

A simplified scheme of the layout of WWTP 1 is presented in Figure 2, and the sampling points are marked.

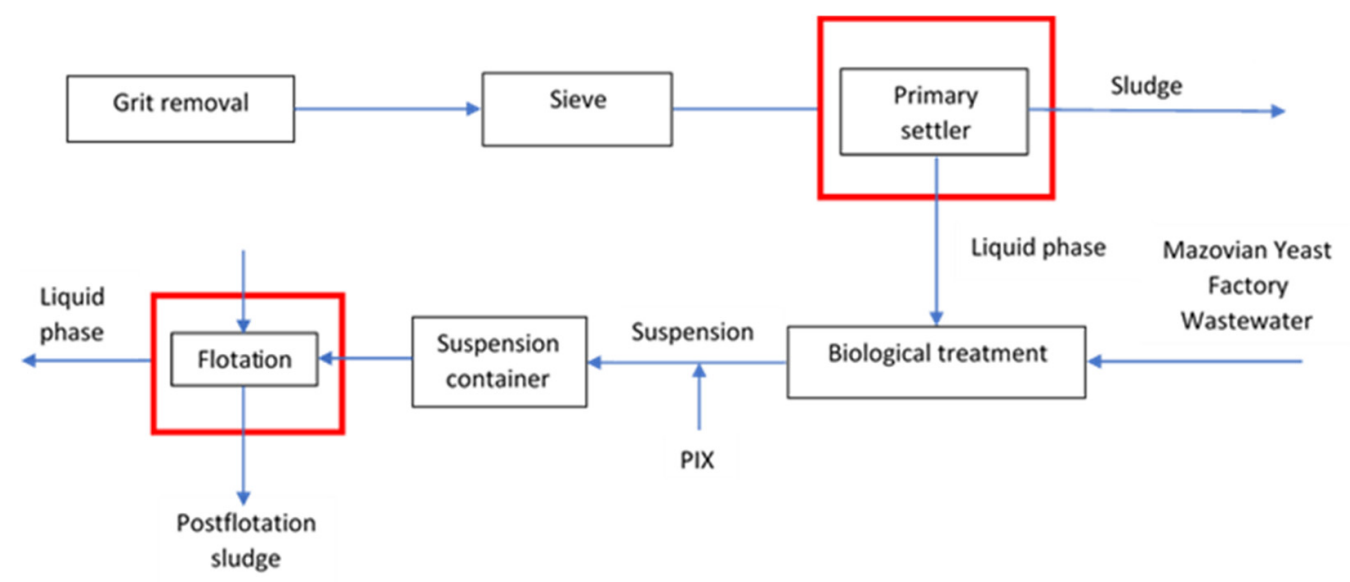

Figure 2. Simplified scheme of WWTP 1. Sampling points are marked with red frames.

The other two types of samples were preliminary sludge from WWTP 2, located around $90 \mathrm{~km}$ east of Warsaw, thickened to $10 \%$ TS. A simplified scheme of the layout of WWTP 2 is given in Figure 3, and the sampling points are marked.

It is important to mention that all works cited in the introduction were related to the processing of redundant sludge (secondary settler-see Figure 2). The results of the testing of other types of sludge presented in this work provide more new information, since in practice, sludge from different points of WWTP may be recovered and utilized. Moreover, the sludge obtained from WWTPs, which were the sources of samples for the experiments presented in this paper, are normally transformed into fertilizer by another company. 


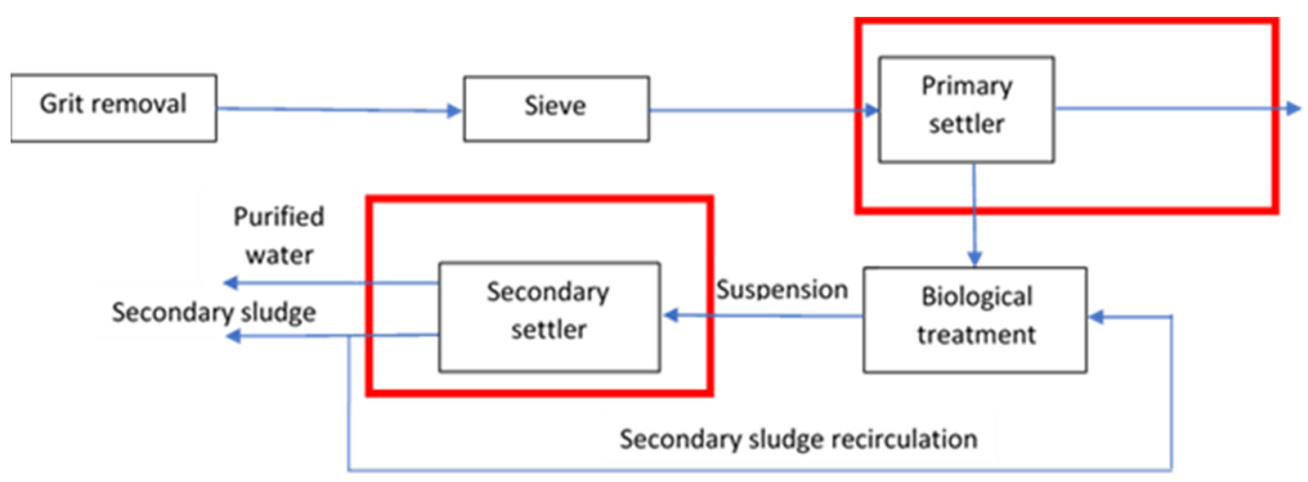

Figure 3. Simplified scheme of WWTP 2. Sampling points are marked with red frames.

Because of the different consistencies of examined sludges two sets of equipment were used for sample irradiation. The first was an ILU $61.7 \mathrm{MeV}$ electron accelerator connected with a laboratory-scale flow irradiation setup (FIS) installation for the flow irradiation of liquids. The installation was built using a peristaltic pump and an aluminum cassette with entrance and exit stub pipes. On the lid of the cassette, a window was cut, and the obtained aperture was covered using $50 \mu \mathrm{m}$ titanium foil to create a closed chamber while enabling the EB to penetrate the layer of liquid inside the cassette. The chamber inside the cassette had dimensions of $140 \times 40 \times 4 \mathrm{~mm}$. A $4 \mathrm{~mm}$ layer thickness ensured full penetration by the $1.7 \mathrm{MeV}$ energy electron beam. Dosimetry measurements were performed by measurements of a $0.1 \mathrm{M}$ alanine water solution conductivity. The prepared solution of alanine was pumped through the irradiation cassette while the accelerator and peristaltic pump worked with defined, preset parameters. Alanine solution irradiation was repeated five times for different peristaltic pump engine speeds. The measured doses were then assigned to the respective engine speed of the pump, and a calibration curve was created. This allowed for later calculations of pump engine speeds necessary to achieve the chosen dose of irradiation. A photo of the system is presented in Figure 4.

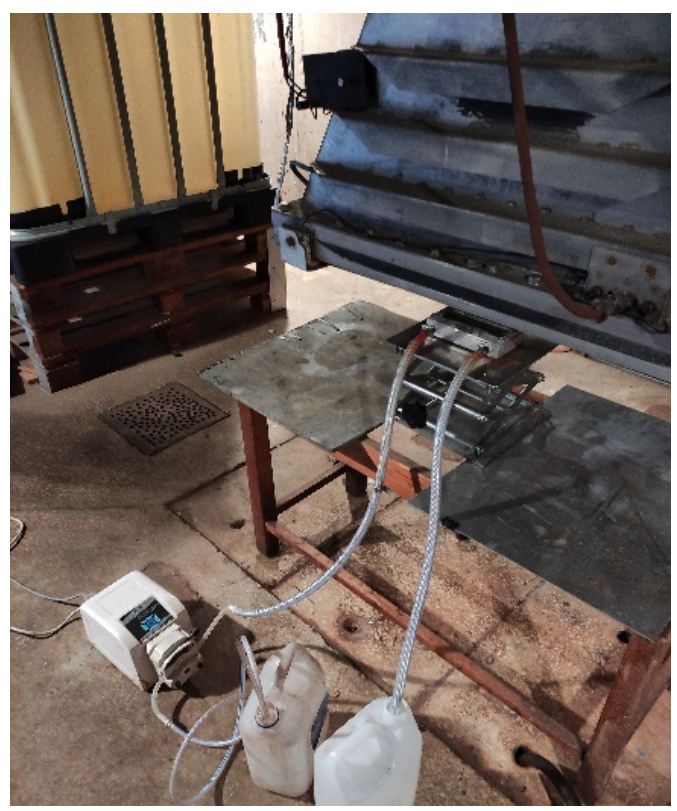

Figure 4. FIS installation used for the flow irradiation of sewage sludge connected to an ILU-6 electron accelerator. Irradiated sludge was pumped by peristaltic pump (on the left) from one container to irradiation cassette located below accelerator exit window (on the top), and then received in the second container (on the bottom). 
Another system used for the tests was the Elektronika 10/10 $10 \mathrm{MeV}$ electron accelerator equipped with a conveyor, normally working in INCT's commercial medical products sterilization plant. Around $1000 \mathrm{~g}$ sludge samples were sealed in polyethylene bags with diameters of $400 \mathrm{~mm} \times 600 \mathrm{~mm}$. The amount of sample was matched to achieve layer thicknesses which did not exceed $10 \mathrm{~mm}$. After such preparation, samples were irradiated. The desired dose was achieved by conveyor speed adjustment, and the dosimetry was created by calorimetric measurements. Moreover, alanine pellets (Aerial, France) were used for each irradiated bag filled with sludge for the dose measurements. The irradiated pellets were later measured using a MagnetTech MS 5000 (Freiberg/Bruker, Germany) EPR spectrometer. A photo of the polyethylene bag with sludge inside is presented in Figure 5.

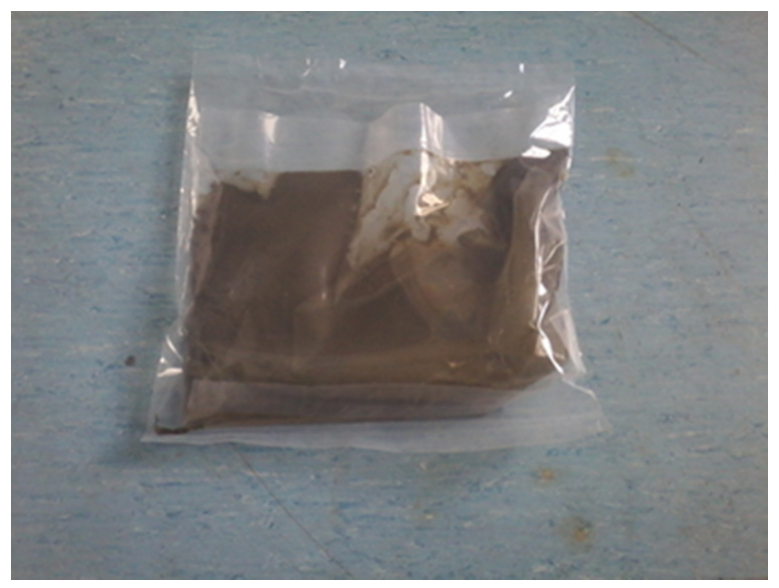

Figure 5. Sample of sewage sludge sealed in a polyethylene bag (120 $\mu \mathrm{m}$ foil thickness) prepared for irradiation by an Elektronika 10/10 electron accelerator.

Next, the irradiated samples were tested commercially for the presence of ATT intestinal parasite eggs, namely human roundworm (Ascaris spp.), animal roundworm (Toxocara spp.) and human whipworm (Trichuris spp.), and for the bacteria Salmonella spp., E. coli and Clostridium perfrigens by laboratory measurements according to the Polish norm: PN-Z-19000-04:2001 improved by the Institute of Rural Medicine (Lublin).

\section{Results and Discussion}

\subsection{Results of Sludge Hygienization-Pathogenic Bacteria}

The results obtained for sludge hygienization related to bacteria removal are provided in Tables below.

The obtained results showed that, for the preliminary sludge from WWTP 1 (Table 1), the dose required to remove all observed bacteria was $4 \mathrm{kGy}$. For the thickened preliminary sludge from WWTP 2 (Table 2), that dose was slightly higher at $5.5 \mathrm{kGy}$, while for the dose of $3.7 \mathrm{kGy}$ (which is nearly $4 \mathrm{kGy}$ ) there were still some bacteria living. For the postflotation sludge (Table 3), the dose required for hygienization was again $4 \mathrm{kGy}$; however, the total bacterial count in that sludge after irradiation at $3 \mathrm{kGy}$ was slightly lower than two other samples. For the preliminary sludge from WWTP 2, the dose for complete elimination of examined bacteria was the highest. This may have been due to fact that WWTP 2 sludge had the highest TS concentration, a few times more than both other samples. El-Motaium et al. showed that the dose necessary to eliminate any bacteria was $6 \mathrm{kGy}$ for sewage sludge and $1 \mathrm{kGy}$ for raw sewage [24]. The authors said that bacteria tent to settle and thus concentrate in the sludge, which explains the necessity to use higher dose of irradiation for sludge. The amount of TS content can affect the number of bacteria cells in sample, however tests in this in this paper cannot confirm that. The analysis of reference samples demonstrated that the number of all bacteria cells was just slightly higher for thickened preliminary sludge $\left(65.29 \times 10^{3} \mathrm{CFU}\right)$ in comparison to preliminary sludge $\left(63.03 \times 10^{3} \mathrm{CFU}\right)$. For postflotation sludge, that number was the lowest $\left(49.77 \times 10^{3} \mathrm{CFU}\right)$. It is also worth mentioning that 
the postflotation sludge was obtained from biologically safe industrial wastewater and the water phase after the settling process of raw municipal wastewater. Moreover, this sludge was obtained after some purification processes partly removed microorganisms, so the numbers of measured bacteria were not as high as in the municipal wastewater sludge, and thus a lower dose to remove them was needed. After irradiation with a $3 \mathrm{kGy}$ dose, the total number of bacteria in the postflotation sludge was four times lower in comparison to preliminary sludge irradiated with the same dose. Additionally, for thickened preliminary sludge, the number of bacteria was still $2.1 \times 10^{3} \mathrm{CFU}$ at the $3.7 \mathrm{kGy}$ dose. For two other samples, almost the same dose was enough to remove all bacteria, while the initial bacteria number was very close for preliminary sludge and thickened preliminary sludge. It is clear that $E$. coli reduction was slower for thickened preliminary sludge than for preliminary sludge, whilst the initial number of this strain was the same for both samples. It is possible that TS concentration is what makes sewage sludge hygienization more difficult.

Table 1. Results of analysis of E.coli, Salmonella spp. and Clostridium perfrigens presence in preliminary sewage sludge from WWTP 1.

\begin{tabular}{ccc}
\hline Dose (kGy) & Detected Species & Result (CFU) \\
\hline \multirow{2}{*}{0} & Escherichia coli, & $6.2 \times 10^{4}$ \\
& Salmonella spp. & $9.2 \times 10^{2}$ \\
& Clostridium perfringens & $1.1 \times 10^{2}$ \\
\hline \multirow{2}{*}{2} & Escherichia coli, & $9.8 \times 10^{3}$ \\
& Salmonella spp. & $1.3 \times 10^{2}$ \\
3 & Clostridium perfringens & $0.9 \times 10^{2}$ \\
\hline \multirow{2}{*}{3} & Escherichia coli, & $1.4 \times 10^{2}$ \\
& Salmonella spp. & $0.4 \times 10^{2}$ \\
& Clostridium perfringens & ca.0.2 $\times 10^{2}$ \\
\hline & Escherichia coli, & none detected \\
& Salmonella spp. & none detected \\
& Clostridium perfringens & none detected \\
\hline & Escherichia coli, & none detected \\
& Salmonella spp. & none detected \\
& Clostridium perfringens & none detected \\
\hline
\end{tabular}

Table 2. Results of the analysis of E.coli, Salmonella spp., and Clostridium perfrigens presence in postflotation sludge from WWTP 1 .

\begin{tabular}{ccc}
\hline Dose (kGy) & Detected Species & Result (CFU) \\
\hline \multirow{2}{*}{0} & Escherichia coli, & $4.9 \times 10^{4}$ \\
& Salmonella spp. & $7.1 \times 10^{2}$ \\
Clostridium perfringens & $0.6 \times 10^{2}$ \\
\hline \multirow{2}{*}{2} & Escherichia coli, & $9.8 \times 10^{3}$ \\
& Salmonella spp. & $0.8 \times 10^{2}$ \\
& Clostridium perfringens & $0.2 \times 10^{2}$ \\
\hline \multirow{2}{*}{3} & Escherichia coli, & $0.4 \times 10^{2}$ \\
& Salmonella spp. & ca.0.1 $\times 10^{2}$ \\
& Clostridium perfringens & none detected \\
\hline & Escherichia coli, & none detected \\
& Salmonella spp. & none detected \\
& Clostridium perfringens & none detected \\
\hline & Escherichia coli, & none detected \\
& Salmonella spp. & none detected \\
& Clostridium perfringens & none detected \\
\hline
\end{tabular}


Table 3. Results of the analysis of E.coli, Salmonella spp. and Clostridium perfrigens presence in preliminary sewage sludge from WWTP 2 .

\begin{tabular}{ccc}
\hline Dose (kGy) & Detected Species & Result (CFU) \\
\hline \multirow{2}{*}{0} & Escherichia coli, & $6.1 \times 10^{4}$ \\
& Salmonella spp. & $4.2 \times 10^{3}$ \\
& Clostridium perfringens & $0.9 \times 10^{2}$ \\
\hline \multirow{2}{*}{1.8} & Escherichia coli, & $6.4 \times 10^{3}$ \\
& Salmonella spp. & $0.3 \times 10^{3}$ \\
& Clostridium perfringens & $0.1 \times 10^{2}$ \\
\hline \multirow{3}{*}{3.7} & Escherichia coli, & $0.2 \times 10^{3}$ \\
& Salmonella spp. & $<0.1 \times 10^{2}$ \\
& Clostridium perfringens & none detected \\
\hline \multirow{3}{*}{5.5} & Escherichia coli, & none detected \\
& Salmonella spp. & none detected \\
& Clostridium perfringens & none detected \\
\hline \multirow{2}{*}{7.5} & Escherichia coli, & none detected \\
& Salmonella spp. & none detected \\
& Clostridium perfringens & none detected \\
\hline & Escherichia coli, & none detected \\
& Salmonella spp. & none detected \\
& Clostridium perfringens & none detected \\
\hline
\end{tabular}

It seems that the bacteria most sensitive to the electron beam are Escherichia coli. For all samples, a dose of $1 \mathrm{kGy}$ reduced the amount of this strain by 1 order of magnitude. Salmonella spp. was slightly more difficult to remove from the WWTP 2 sludge. The most resistant to irradiation seemed to be Clostridium perfringens, especially in WWTP 2 sludge. In that case, the differences in the number of bacteria after each dose of irradiation were the lowest; on the other hand, this strain was the least numerous, which is why it was removed sooner than the rest of the measured bacteria.

\subsection{Results of Sludge Hygienization-Helminths Eggs}

The results obtained for sludge hygienization related to living helminths eggs are provided in the Tables below.

As for the bacteria, the dose required for living helminths eggs removal from postflotation sludge and preliminary sludge from WWTP 1 (Table 4) was $4 \mathrm{kGy}$, for postflotation sludge (Table 5) it was again 4 kGy, while for WWTP 2 (Table 6) sludge it was $5.5 \mathrm{kGy}$. These differences could have been caused by the significantly higher amount of TS in the WWTP 2 sludge. Notably, all of the reference samples examined, taken from different places, were almost equally abundant in particular helminth species eggs, while differences between TS content for each sludge type were significant. The most numerous ones were Ascaris spp. eggs, then Trichuris spp. and lastly Toxocara spp. This finding may indicate which species of human parasite is the most common in the region. The postflotation sludge had the least amount of helminths eggs in comparison to other two examined samples for the same reason as in the bacteria-number tests. It is worth emphasizing that the number of ATT in preliminary sludge and thickened preliminary sludge were very close, while TS concentration for thickened sludge was 2.5 times higher than TS concentration for preliminary sludge. Additionally, in this case it can be observed again that TS concentration affects the dose required for complete hygienization, more so than the initial number of pathogens. Nevertheless, dangerous pathogens are present in all tested sludges, which is why all types of sludge taken from WWTPs should be hygienized before any form of utilization. 
Table 4. Results of the analysis for presence of living eggs of helminths: Toxocara spp., Trichuris spp. and Ascaris spp. in preliminary sewage sludge from WWTP 1.

\begin{tabular}{ccc}
\hline Dose (kGy) & Detected Species & Result (Number of Living Eggs) \\
\hline \multirow{2}{*}{0} & Ascaris spp. & 21 \\
& Trichuris spp. & 9 \\
Toxocara spp. & 3 \\
\hline \multirow{2}{*}{2} & Ascaris spp. & 16 \\
& Trichuris spp. & 4 \\
Toxocara spp. & 1 \\
\hline \multirow{2}{*}{3} & Ascaris spp. & 4 \\
& Trichuris spp. & none detected \\
& Toxocara spp. & none detected \\
\hline \multirow{2}{*}{4} & Ascaris spp. & none detected \\
& Trichuris spp. & none detected \\
& Toxocara spp. & none detected \\
\hline \multirow{2}{*}{5} & Ascaris spp. & none detected \\
& Trichuris spp. & none detected \\
& Toxocara spp. & none detected \\
\hline
\end{tabular}

Table 5. Results of the analysis for the presence of living eggs of helminths: Toxocara spp., Trichuris spp. and Ascaris spp. in postflotation sludge from WWTP 1.

\begin{tabular}{ccc}
\hline Dose (kGy) & Detected Species & Result (Number of Living Eggs) \\
\hline \multirow{2}{*}{0} & Ascaris spp. & 17 \\
& Trichuris spp. & 4 \\
Toxocara spp. & 2 \\
\hline \multirow{2}{*}{2} & Ascaris spp. & 11 \\
& Trichuris spp. & 1 \\
& Toxocara spp. & none detected \\
\hline \multirow{2}{*}{3} & Ascaris spp. & 3 \\
& Trichuris spp. & none detected \\
& Toxocara spp. & none detected \\
\hline \multirow{2}{*}{4} & Ascaris spp. & none detected \\
& Trichuris spp. & none detected \\
& Toxocara spp. & none detected \\
\hline \multirow{2}{*}{5} & Ascaris spp. & none detected \\
& Trichuris spp. & none detected \\
& Toxocara spp. & none detected \\
\hline
\end{tabular}

Table 6. Results of the analysis for the presence of living eggs of helminths: Toxocara spp., Trichuris spp. and Ascaris spp. in preliminary sewage sludge from WWTP 2.

\begin{tabular}{ccc}
\hline Dose (kGy) & Detected Species & Result (CFU) \\
\hline & Ascaris spp. & 27 \\
0 & Trichuris spp. & 9 \\
& Toxocara spp. & 4 \\
\hline \multirow{2}{*}{1.8} & Ascaris spp. & 16 \\
& Trichuris spp. & 6 \\
\hline & Toxocara spp. & 7 \\
& Ascaris spp. & 2 \\
\end{tabular}


Table 6. Cont.

\begin{tabular}{ccc}
\hline Dose (kGy) & Detected Species & Result (CFU) \\
\hline \multirow{2}{*}{5.5} & $\begin{array}{c}\text { Ascaris spp. } \\
\text { Trichuris spp. } \\
\text { Toxocara spp. }\end{array}$ & $\begin{array}{l}\text { none detected } \\
\text { none detected } \\
\text { none detected }\end{array}$ \\
\hline \multirow{2}{*}{7.5} & Ascaris spp. & none detected \\
& Trichuris spp. & none detected \\
& Toxocara spp. & none detected \\
\hline & Ascaris spp. & none detected \\
& Trichuris spp. & none detected \\
& Toxocara spp. & none detected
\end{tabular}

\section{Conclusions}

These experiments have proven that the irradiation doses delivered using electron beams required to remove biological threat are $4 \mathrm{kGy}$ for preliminary sludge with about $4 \%$ TS and for postflotation sludge with $2.5 \%$ TS, and $5.5 \mathrm{kGy}$ for preliminary sludge thickened to about $12 \%$ TS. These data refer to the destruction of both pathogenic bacteria and helminth eggs. Obtained results also showed that the more thickened the sludge is, the higher the dose needed to remove all pathogens. However, the density of thickened sludge is still similar to the density of water, so increasing TS concentration should not affect the beam penetration depth when leaving the same thickness of the irradiated sludge layer. Therefore, two types of accelerators were tested, one with beam energy of $1.7 \mathrm{MeV}$ and another providing electrons with energy of $10 \mathrm{MeV}$. These data gave us sufficient information to build a pilot plant using this electron beam design.

The presence of helminths eggs in sewage sludge obtained from municipal wastewater is still a current problem. All types of sludges tested in this work contained parasite eggs, even postflotation sludge though it was obtained from the liquid phase of municipal wastewater. Thus, any type of sludge obtained in WWTP can be infected with pathogens that are dangerous to humansF, and the thought of farmers spreading sewage sludge on their fields without any previous processing is increasingly worrying. A hygienization process of any type of sewage sludge is strictly needed before agricultural utilization of such sludge.

Author Contributions: Conceptualization, A.G.C.; methodology, A.G.C., M.S.; investigation, M.S.; writing-original draft preparation, M.S., A.G.C.; writing-review and editing, A.G.C., M.S. All authors have read and agreed to the published version of the manuscript.

Funding: This research was performed in frame of the Ministry of Science and Higher Education Project no. 411946: "A Method for Hygienisation of Sewage Sludge Based on Electron Accelerator Application" W48/IAEA/2018, IAEA RC 22642 and "A Method for Hygienisation of Sewage Sludge Based on Electron Accelerator Application" in the framework of CRP F23033. "Radiation Inactivation of Bio-hazards Using High Powered Electron Beam Accelerators".

Institutional Review Board Statement: Not applicable.

Informed Consent Statement: Not applicable.

Acknowledgments: Special thanks to Gea Nova Sp. Z o.o., a company that delivered us sewage sludge samples for the experiment. We also thank the Ziemia Polska Sp. Z o.o. company for delivering another type of sludge for the tests.

Conflicts of Interest: The authors declare no conflict of interest. 


\section{References}

1. Dymaczewski, Z.; Oleszkiewicz, J.A.; Sozański, M.M. Manual for Treatment Plant Operators. (Poradnik Eksploatatora Oczyszczalni Ścieków), 2nd ed.; Polskie Zrzeszenie Inżynierów i Techników Sanitarnych: Poznań, Poland, 1997. (In Polish)

2. Chahal, C.; van den Akker, B.; Young, F.; Fran-co, C.; Blackbeard, J.; Monis, P. Pathogen and Particle Associations in Wastewater: Significance and Implications for-Treatment and Disinfection Processes. Adv. Appl. Microbiol. 2016, 97, 63-119. [PubMed]

3. Central Statistical Office of Poland. Statistical Yearbook of the Republic of Poland; Statistics Poland: Warsaw, Poland, 2006; 2011, p. 2015. Available online: stat.gov.pl (accessed on 1 August 2021).

4. Regulation of Minister of Environment of 16th of July 2015 on Admission of Wastes to Storage on Landfills. Available online: http:/ /isap.sejm.gov.pl/isap.nsf/download.xsp/WDU20150001277/O/D20151277.pdf (accessed on 16 August 2021).

5. Regulation of Minister of Environment of 6th of February 2015 on Municipal Sewage Sludge. Available online: http:/ /isap.sejm. gov.pl/isap.nsf/download.xsp/WDU20150000257/O/D20150257.pdf (accessed on 15 August 2021).

6. Amahmid, O.; Asmama, S.; Bouhoum, K. Urban wastewater treatment in stabilization ponds: Occurrence and removal of pathogens. Urban Water J. 2002, 4, 255-262. [CrossRef]

7. Chaouaa, S.; Boussaaa, S.; Khadraa, A.; Boumezzougha, A. Efficiency of two sewage treatment systems (activated sludge and natural lagoons) for helminth egg removal in Morocco. J. Infect. Public Health 2018, 11, 197-202. [CrossRef] [PubMed]

8. Zdybel, J.; Cencek, T.; Karamon, J.; Kłapeć, T. Effectiveness of selected stages of wastewater treatment in elimination of eggs of intestinal parasites. Bull. Vet. Inst. Pulawy 2015, 59, 51-57. [CrossRef]

9. Zdybel, J.; Karamon, J.; Dabrowska, M.; Różycki, E.; Bilska-Zając, T.; Kłapeć, T.; Cencek, T. Parasitological contamination with eggs Ascaris spp., Trichuris spp. and Toxocara spp. of dehydrated municipal sewage sludge in Poland. Environ. Pol. 2019, 248, 621-626. [CrossRef] [PubMed]

10. Hudzik, G.; Wodzisławska-Czapla, D. Threats related to the presence of eggs of intestinal parisites in sludge. Przegl. Epidemiol. 2011, 65, 459-461. (In Polish) [PubMed]

11. Bobrowski, K. Radiation chemistry of liquid systems. In Applications of Ionizing Radiation in Material Processing; Sun, Y., Chmielewski, A.G., Eds.; Institute of Nuclear Chemistry and Technology: Warsaw, Poland, 2017; pp. 81-88.

12. Bacq, Z.M.; Alexander, P. Fundamentals of Radiobiology; Pergamon Press: London, UK, 1966.

13. Garg, N.K.; Varshney, L. Gamma Radiation Technology for Hygienization of Municipal Dry Sewage Sludge. Energy Environ. 2018, 80, 103-106.

14. Priyadarshini, J.; Roy, P.K.; Mazumdar, A. Qualitative and quantitative assessment of sewage sludge by gamma irradiation with pasteurization as a tool for hygienization. J. Inst. Eng. (India) 2014, 95, 49-54. [CrossRef]

15. Lessel, T.; Hennig, E. The Pilot Plant in Geiselbullach for the Gamma Irradiation, Operation, Experience and Cost Calculations. Available online: https://inis.iaea.org/collection/NCLCollectionStore/_Public/08/330/8330700.pdf (accessed on 21 September 2021).

16. Chmielewski, A.G.; Zimek, Z.; Bryl-Sandelewska, T.; Kosmal, W.; Kalisza, L.; Kaźmierczuk, M. Disinfection of municipal sewage sludges in installation equipped with electron accelerator. Radiat. Phys. Chem. 1995, 46, 1071-1074. [CrossRef]

17. Kim, Y.; Han, B.; Kim, J.K.; Ben Yaacov, N.; Jeong, K.Y. Design of electron beam sludge hygienization plant. In Proceedings of the International Topical Meeting on Nuclear Research Applications and Utilization of Accelerators, Vienna, Austria, 4-8 May 2009. Available online: https://pdfs.semanticscholar.org/81ff/f088f4e2fbea265d8faa685f83b47c53a800.pdf (accessed on 30 October 2019).

18. Naign, T.T.; Lay, K.K. Utilization of gamma radiation in industrial wastewater treatment. Int. J. Mech. Prod. Eng. 2015, 3, 1-5.

19. Chu, L.; Wang, J.; Wang, B. Effect of gamma irradiation on activities and physiochemical characteristics of sewage sludge. Biochem. Eng. J. 2011, 45, 34-39. [CrossRef]

20. Engohang-Ndong, J.; Uribe, R.M.; Gregory, R.; Gangoda, M.; Nickelsen, M.G.; Loar, P. Effect of electron beam irradiation on bacterial and Ascaris ova loads and volatile organic compounds in municipal sewage sludge. Radiat. Phys. Chem. 2015, $112,6-12$. [CrossRef]

21. Blach, M.I.; Scarpino, P.V.; O’Donnell, C.J.; Meyer, K.B.; Jones, J.V.; Kaneshiro, S.E. Survival rates of parasite eggs in sludge during aerobic and anaerobic digestion. Appl. Environ. Microbiol. 1982, 44, 1138-1143. [CrossRef]

22. Franke-Whittle, I.H.; Insam, H. Treatment alternatives of slaughterhouse wastes, and their effect on the inactivation of different pathogens: A review. Crit. Rev. Microbiol. 2013, 39, 139-151. [CrossRef] [PubMed]

23. Seruga, P.; Krzywonos, M.; Paluszak, Z.; Urbanowska, A.; Pawlak-Kruczek, H.; Niedźwiecki, Ł.; Pieńkowska, H. Pathogen Reduction Potential in Anaerobic Digestion of Organic Fraction of Municipal Solid Waste and Food Waste. Molecules 2020, 25, 275. [CrossRef]

24. El-Motaium, R.; Ezzat, H.E.M.; Et-Batanony, M.; Kreuzig, R.; Abo-El.Seoud, M. Irradiated Sewage Sludge for Increased Crop Production-I. Pathogens and Poly-Cyclic Aromatic Hydrocarbons; IAEA-TECDOC-CD-1317; International Atomic Energy Agency: Vienna, Austria, 2002; pp. 67-73. Available online: https://inis.iaea.org/search/search.aspx?orig_q=RN:34010893 (accessed on 30 October 2019). 